\title{
Studies on Determination Methods for Base Numbers of Lubricating Oils and Additives*
}

\author{
by Fumio Toida** and Kazuo Uchinuma**
}

\begin{abstract}
Summary: Perchloric acid titration in glacial acetic acid solvent (acelic acid method) has been proposed by Abbott and Farley for determining base numbers of basic lubricating additives and blended oils. This method is useful for new oils; however, it can not be generally applied to used oils, since sharp inflection sometimes does not appear in the titration curve. This defect is eliminated by introducing a back titration tequnique using sodium acetate as titrant (backward acetic acid method) into the original method.

$A$ remarkable difference has been observed between the base numbers of used engine oils determined by the standard JIS K 2502 method (equivalent to ASTM D 664 and IP 177) and the backward acetic acid method. The laboratory analyses have indicated that the backward acetic acid method gives the valid value as to the neutralizing capacity for sulfuric acid which is the most corrosive substance in the diesel engine, while the JIS method gives unreasonably low value. The base number determined by the backward acetic acid method has been also proved by engine tests to be valid. When a used oil sample from marine service and some of the new oils are tested, the used oil shows engine performance equivalent to the new oil of about the same base number by the backward acetic acid method.

It has been found that the reason for the JIS method giving lower values for used oils is due to the components contained more in the used oil than in the new oil, which may be difficult to titrate accurately by the JIS method.
\end{abstract}

\section{Introduction}

As is well known, the base number is one of the important properties of engine lubricating oils, especially of marine diesel engine oils. The base number represents the ability of engine oils to neutralize acidic products such as sulfuric acid generated from the combustion of sulfur compounds in the fuel which promotes engine wear and deposit ${ }^{11}$. In used oil analyses, the base number is useful for the estimation of oil deterioration or oil-change period ${ }^{2) ~ 4)}$.

It is evident that a reliable method is necessary to determine the base number of oils and additives compounded in them. However, it has been pointed out that the standard JIS K 2502 method $^{5)}$ now in general use for determining the base number of petroleum products is not entirely satisfactory for organo-metallic additives, and therefore improvement of this method or development of a new method has become desirable.

Abbott and Farley ${ }^{6}$ ) have shown that the acetic acid method gives the results essentially identical with the theoretical values, and more correlative

* Received November 13, 1969.

** Central Technical Research Laboratory, Nippon Oil Co., Ltd. (2-3-2, Yako, Kawasaki, Japan) with engine wear than those by the ASTM D 664 method.

The purpose of this study is to re-examine the acetic acid method, and to develop a modified technique (the backward acetic acid method), which is generally applicable to used oils; and then to show the validity of the base number determined by this method.

\section{Re-examination of the Acetic Acid Method}

The acetic acid method and the sulfuric acid back titration method selected from Abbott and Farley's paper6), and the methyl isobutyl ketone method previously proposed by Oronite Chemical Co., ${ }^{7)}$ were compared with the JIS K 2502 method as regards their accuracy, precision and rapidness. The summary of each method is given in Table 1.

Experiments were carried out by using Beckman Zeromatic $\mathrm{pH}$ meter with Beckman glass electrode No. 41260 and Töyörika calomel electrode MR-13, and each sample was analyzed twice by the same operator.

Table 2 shows the accuracy expressed as percent of the theoretical value. The acetic acid method gives the results which agree well within $\pm 5^{\circ}$ of the theoretical values for most of the samples. 
Table 1 Summary of Methods

\begin{tabular}{|c|c|c|c|c|}
\hline & $\begin{array}{l}\text { JIS K } 2502 \text { Method } \\
\text { (ASTM D 664) }\end{array}$ & $\begin{array}{l}\text { Sulfuric Acid Back } \\
\text { 'Titration Method }\end{array}$ & $\begin{array}{l}\text { Methyl Isobutyl } \\
\text { Ketone Method }\end{array}$ & Acetic Acid Method \\
\hline $\begin{array}{l}\text { Titration } \\
\text { Solvents }\end{array}$ & $\begin{array}{l}\text { Mixture of } 49.5 \% \text { iso- } \\
\text { propyl alcohol, } 50.0 \% \\
\text { toluene and- } 0.5 \% \\
\text { water, } 125 \mathrm{~m} l\end{array}$ & $\begin{array}{l}\text { Same as JIS K } 2502 \\
\text { Method }\end{array}$ & $\begin{array}{l}\text { Mett.yl isobutyl ketone } \\
100 \mathrm{~m} l \text { and toluene } \\
10 \mathrm{~m} l\end{array}$ & $\begin{array}{l}\text { Glacial acetic acid } 100 \\
\mathrm{~m} l \text { and toluene } 10 \mathrm{~m} l\end{array}$ \\
\hline Titrants & $\begin{array}{l}0.1 N \mathrm{HCl} \text { in isopropyl } \\
\text { alcohol }\end{array}$ & 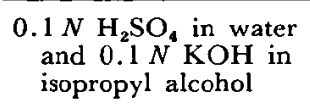 & $\begin{array}{l}0.1 \mathrm{~N} \mathrm{HClO}_{4} \text { in glacial } \\
\text { acetic acid }\end{array}$ & $\begin{array}{l}0.1 \mathrm{~N} \mathrm{HClO}_{4} \text { in glacial } \\
\text { acetic acid }\end{array}$ \\
\hline End Points & $\begin{array}{l}\text { Inflection point, or } \mathrm{pH} \\
\text { reading corresponding } \\
\text { to the nonaqueous } \\
\text { acidic buffer solution* }\end{array}$ & Inflection point & Inflection point & Inflection point \\
\hline
\end{tabular}

* It is chosen if no sharp inflection appears. In any case of this study, the end points are determined by the $\mathrm{pH}$ readings.

Table 2 Comparison of Base Numbers by Various Methods

\begin{tabular}{|c|c|c|c|c|c|}
\hline & \multirow{2}{*}{$\begin{array}{l}\text { Theoretical } \\
\text { Base Number } \\
\text { (mg KOH/g) }\end{array}$} & \multicolumn{4}{|c|}{ Percent of Theory } \\
\hline & & $\underset{\text { Method }}{\text { JIS K } 2502}$ & $\begin{array}{l}\text { Sulfuric Acid } \\
\text { Back Titration } \\
\text { Method }\end{array}$ & $\begin{array}{l}\text { Methyl Iso- } \\
\text { butyl Ketone } \\
\text { Method }\end{array}$ & $\begin{array}{l}\text { Acetic Acid } \\
\text { Method }\end{array}$ \\
\hline $\begin{array}{l}\text { Basic Calcium Sulfonate } \\
\text { High Basic Calcium Sulfonate } \\
\text { Basic Barium Sulfonate }\end{array}$ & $\begin{array}{c}19.9 \\
285 \\
47.5\end{array}$ & $\begin{array}{r}92 \\
100 \\
70\end{array}$ & $\begin{array}{r}90 \\
100 \\
80\end{array}$ & $\begin{array}{r}94 \\
102 \\
78\end{array}$ & $\begin{array}{r}95 \\
102 \\
81\end{array}$ \\
\hline $\begin{array}{l}\text { Basic Calcium Phenate } \\
\text { High Basic Calcium Phenate } \\
\text { Basic Barium Phenate }\end{array}$ & $\begin{array}{l}128 \\
246 \\
79.2\end{array}$ & $\begin{array}{l}94 \\
87 \\
86\end{array}$ & $\begin{array}{l}97 \\
92 \\
83\end{array}$ & $\begin{array}{l}96 \\
93 \\
83\end{array}$ & $\begin{array}{r}102 \\
103 \\
95\end{array}$ \\
\hline $\begin{array}{l}\text { Marine Lubricating Oil A } \\
\text { Marine Lubricating Oil B } \\
\text { Marine Lubricating Oil C } \\
\text { Marine Lubricating Oil D }\end{array}$ & $\begin{array}{l}6.43 \\
10.2 \\
30.8 \\
49.5\end{array}$ & $\begin{array}{l}91 \\
90 \\
86 \\
86\end{array}$ & $\begin{array}{l}98 \\
98 \\
96 \\
92\end{array}$ & $\begin{array}{r}104 \\
102 \\
100 \\
93\end{array}$ & $\begin{array}{l}107 \\
103 \\
102 \\
100\end{array}$ \\
\hline
\end{tabular}

The methyl isobutyl ketone method and the sulfuric acid back titration method also give the results which agree fairly well with theory, but not so excellently as does the acetic acid method. The JIS method gives significantly lower results for most of the samples. As to the barium additives, all of the methods give significantly lower results, though clear inflection was obtained with all the methods except for the JIS method. The reason for this is not clear.

Table 3 shows the precision data calculated by the ASTM-proposed practice ${ }^{8)}$. The methyl isobutyl ketone method, the acetic acid method, and the sulfuric acid back titration method show satisfactory repeatability, while that of the JIS method is appreciably worse.

Reproducibility of the acetic acid method is three times better than that of the JIS method.

As to the time required for titration, it took only $15-20$ minutes to titrate a sample by the acetic acid method, while it took $40-60$ minutes by the other three methods.
Table 3 Precision ${ }^{a)}$ of Various Methods

\begin{tabular}{l|c|c}
\hline & $\begin{array}{c}\text { Repeatability }) \\
(\%)\end{array}$ & $\begin{array}{c}\text { Reproduci- } \\
\text { bilityc) }(\%)\end{array}$ \\
\hline $\begin{array}{c}\text { JIS K 2502 Method } \\
\text { Sulfuric Acid Back } \\
\text { Titration Method }\end{array}$ & 7.5 & 15 \\
$\begin{array}{c}\text { Methyl Isobutyl } \\
\text { Ketone Method }\end{array}$ & 0.6 & - \\
Acetic Acid Method & 3 & - \\
\hline
\end{tabular}

a) The greatest difference between the duplicate results that can be considered acceptable at the 95\% probability level.

b) Results by the same operator using all samples shown in Table 2.

c) Results by four laboratories using marine lubricating oil B, C, D (Table 2) and DS grade diesel oil.

From these facts, it is confirmed that the acetic acid method is superior to the other three. This conclusion agrees with that of Abbott and Farley.

\section{Base Number Determination of Used Oils by the Acetic Acid Method}

The base number determination of used oils is necessary for evaluating their useful life. How- 
ever, the results given in Table 4 show that the acetic acid method can not determine reliable base numbers for about a half of the used oil samples, because clear inflections do not appear. The typical titration curves for used oils are shown in Fig. 1 in comparison with those for new oils. The reason why the inflection is not sharp for used oils may be explained by the interference of the impurities present such as half-neutralized additives, oxidized products, dust and worn off

Table 4 Base Numbers of New and Used Oils

\begin{tabular}{|c|c|c|c|c|}
\hline & \multicolumn{4}{|c|}{ Base Number (mg KOH/g) } \\
\hline & $\begin{array}{c}\text { JIS K } \\
2502 \\
\text { Method }\end{array}$ & $\begin{array}{r}\text { Aceti } \\
\mathbf{M e}\end{array}$ & $\begin{array}{l}\text { Acid } \\
\text { thod }\end{array}$ & $\begin{array}{l}\text { Backward } \\
\text { Acetic } \\
\text { Acid } \\
\text { Method }\end{array}$ \\
\hline $\begin{array}{l}\text { DM Grade Diesel Oil } \\
\text { New } \\
\text { Used in Metro- } \\
\text { politan Bus } \\
1,251 \mathrm{~km} \\
2,507 \mathrm{~km} \\
3,393 \mathrm{~km} \\
4,017 \mathrm{~km}\end{array}$ & $\begin{array}{l}5.66 \\
4.44 \\
4.30 \\
4.12\end{array}$ & $\begin{array}{c}8.48 \\
\\
7.13 \\
* 6.76 \\
* 6.87 \\
\times\end{array}$ & $\begin{array}{c}8.50 \\
\\
7.23 \\
\times \\
\times 6.59 \\
\times\end{array}$ & $\begin{array}{l}8.42 \\
\\
7.24 \\
6.25 \\
5.32 \\
4.71\end{array}$ \\
\hline $\begin{array}{l}\text { Marine Cylinder Oil } \\
\text { New } \\
\text { Used in Bolnes } \\
\text { Engine Test } \\
\text { Mix. of } 1: 1 \mathrm{New} \\
\text { and Used } \\
36 \mathrm{hr}\end{array}$ & $\begin{array}{r}27.6 \\
7.40\end{array}$ & $\begin{array}{r}33.3 \\
\times\end{array}$ & $\begin{array}{r}48.2 \\
33.6 \\
\times\end{array}$ & $\begin{array}{l}34.5 \\
21.5\end{array}$ \\
\hline $\begin{array}{l}\text { Marine Cylinder Oil } \\
\text { New } \\
\text { Used in Bolnes } \\
\text { Engine Test } \\
\text { Mix. of I : i New } \\
\text { and Used } \\
36 \mathrm{hr}\end{array}$ & $\begin{array}{l}28.1 \\
10.5\end{array}$ & $\begin{array}{r}33.8 \\
\times\end{array}$ & $\begin{array}{r}34.1 \\
\times\end{array}$ & $\begin{array}{l}34.6 \\
23.8\end{array}$ \\
\hline $\begin{array}{l}\text { Used Marine Lubri- } \\
\text { cating Oil } \\
\text { Service Sample } \\
\text { No. } 1 \\
\text { No. } 2\end{array}$ & $\begin{array}{l}2.38 \\
1.36\end{array}$ & $\begin{array}{c}* 5.05 \\
\times\end{array}$ & $\begin{array}{l}x \\
x\end{array}$ & $\begin{array}{l}4.14 \\
2.43\end{array}$ \\
\hline
\end{tabular}

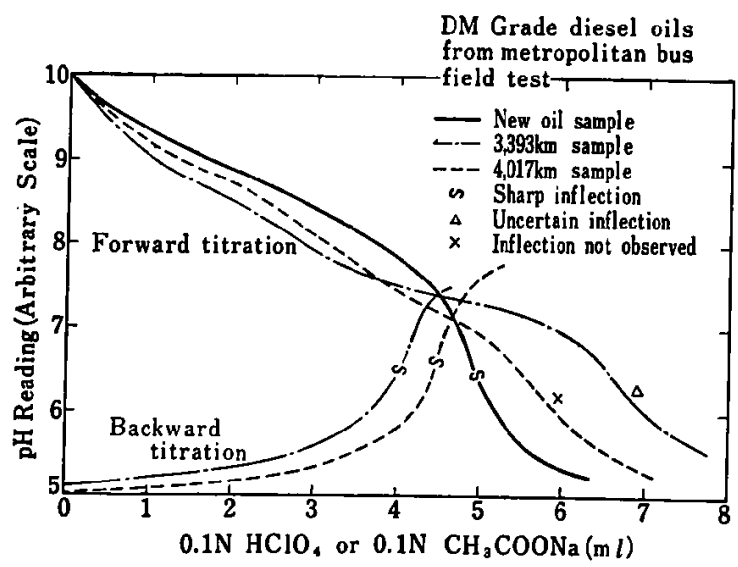

Fig. 1 Titration Curves of New and Used Oils by Forward and Backward Acetic Acid Methods metals which have different base characteristics. These results suggest that the acetic acid method is not generally applicable to used oils.

\section{Backward Acetic Acid Method}

In order to eliminate the defect of the acetic acid method in the case of used oils, a modified technique (the backward acetic acid method) has been employed. The solvent in the backward method is the same as in the acetic acid method (glacial acetic acid $100 \mathrm{~m} l+$ toluene $10 \mathrm{~m} l$ ). After dissolving the sample in the solvent, the excess amount of $0.1 \mathrm{~N}$ acetous perchloric acid solution $(8 \mathrm{~m} l)$ is added, and stirred for about 1-2 minutes until the equilibrium is reached. The unneutralized acid is titrated with $0.1 \mathrm{~N}$ acetous sodium acetate solution. The amount of acid required to neutralize the base components in the sample is calculated from the difference between the blank and back titration. The 0.1N acetous sodium acetate solution is prepared by dissolving sodium carbonate in glacial acetic acid solvent to change it to sodium acetate. Standardization of this solution is unnecessary, as the primary standard grade sodium carbonate is available.

As shown in Table 5, the backward acetic acid method gives the base numbers essentially identical with those by the forward acetic acid method for additives and new oils.

The backward method gives clear inflections for used oils as seen in Fig. 1. The base numbers of some used oils are given in Table 4.

However, in a series of additional determinations, it has been found that there are appre-

Table 5 Comparison of Forward and Backward Acetic Acid Methods

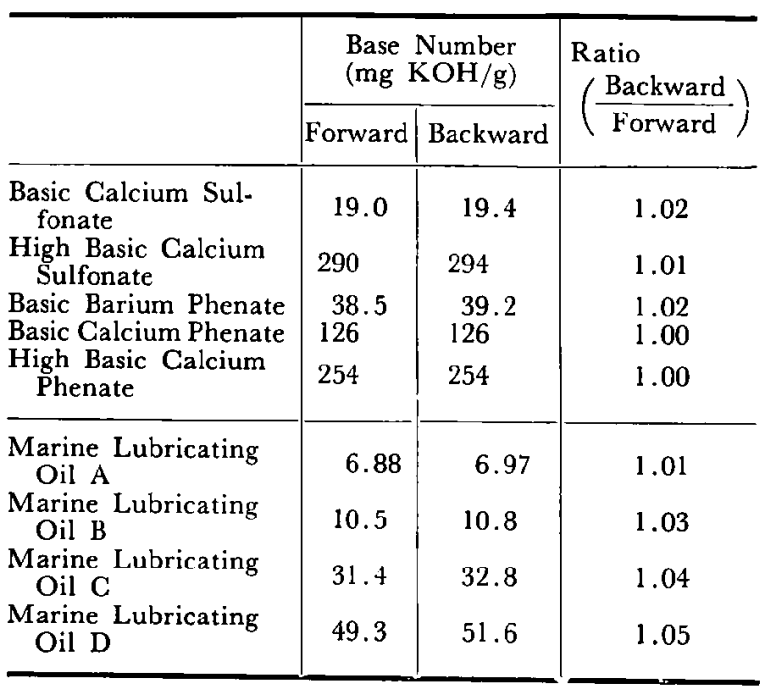




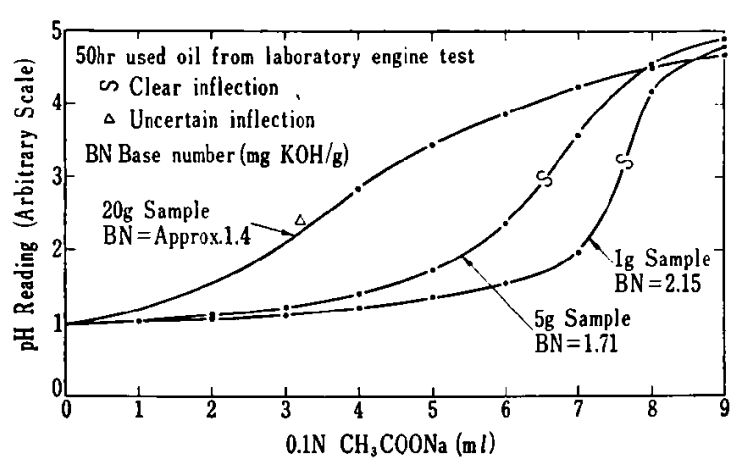

Fig. 2 Effect of Sample Size on Titration Curves in the Backward Acetic Acid Method

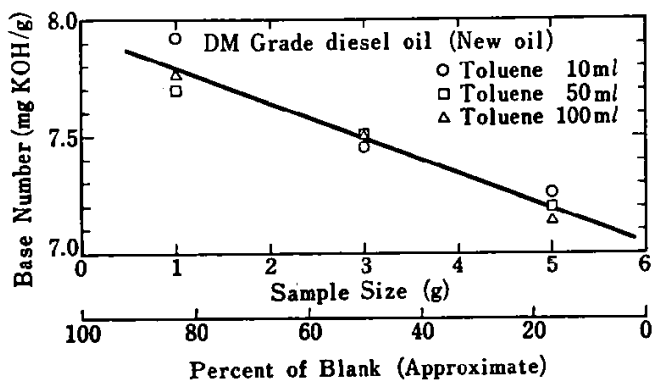

Fig. 3 Effect of Sample Size and Amount of Toluene on Base Number

ciable scatterings in the replicate determinations. Fig. 2 indicates the influence of sample size. The base number decreases with increasing sample size. It is considered from this result that the scattering would be caused by insufficient solubility due to a too small amount of toluene in the titration solvent. However, Fig. 3 shows that increasing the amount of toluene up to $100 \mathrm{ml}$ does not compensate the influence of sample size, though the solution is apparently homogeneous when the amount of toluene exceeds about $50 \mathrm{~m} l$. Fig. 4 also shows the influence of sample size for samples containing several additives. From Fig. 4 , it is not always true that titration with a larger sample size, that is, one with the smaller ratio of back titration to blank titration, yields a lower value. It is interesting that the effect of sample size varies with the type of zinc dialkyldithiophosphates (designated as $\mathrm{A}$ and $\mathrm{B}$ according to the alkyl group of the compound). The base numbers of these antioxidants by the backward acetic acid method were $0.4-1.5 \mathrm{mgKOH} / \mathrm{g}$. Although the increase of base number by the addition of one percent antioxidant should be negligible, the measured base numbers are out of the range of the expected values. The reason why the base number is affected by sample size and by the

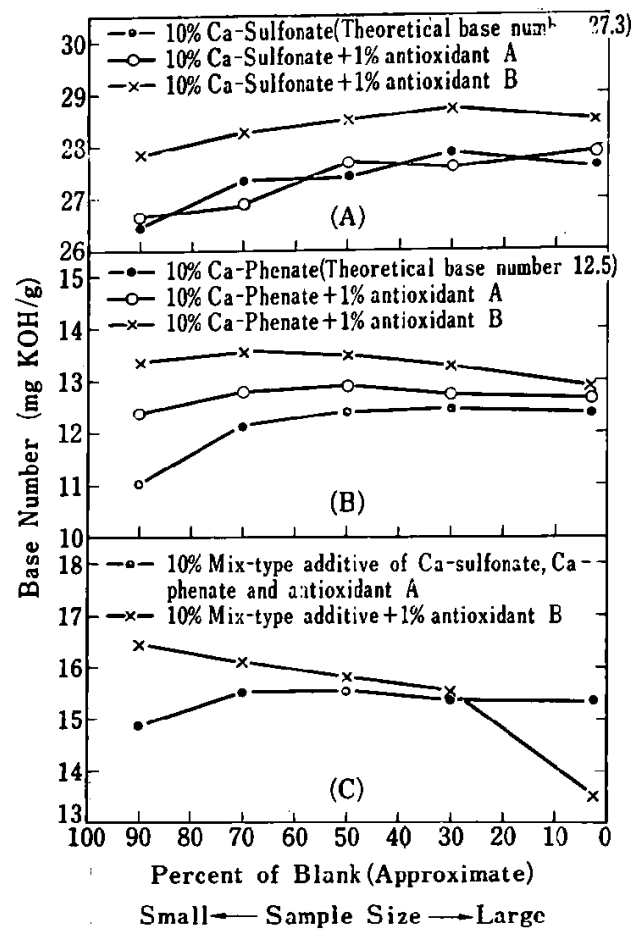

Fig. 4 Effert of Sample Size on Base Number (New Oils)

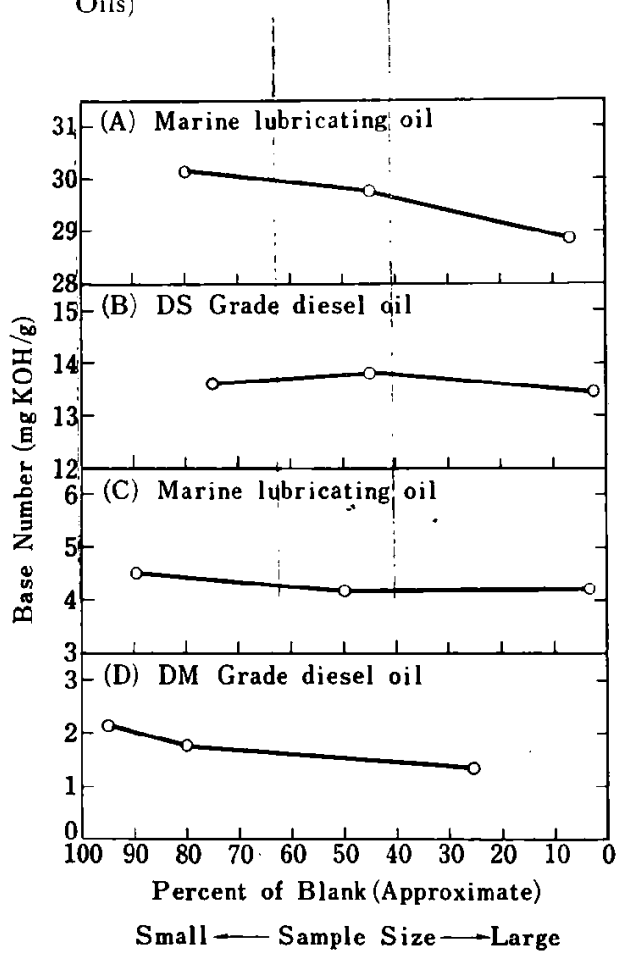

Fig. 5 Effect of Sample Size on Base Number (Used Oils)

presence of antioxidants is not known. However, these effects can be reduced within the allowable range by keeping the back titration from 30 to 70 percent of the blank. It is also shown in Fig. 5 that precision for used oils is satisfactory, if the sample size is properly chosen. 
5 Difference between the Base Numbers by the JIS and the Backward Acetic Acid Methods

Before introducing the backward acetic acid method instead of the JIS method for used oil routine analyses, the comparison of the base numbers by both methods should be made. An example of these results is shown in Fig. 6. There is a remarkable difference between the base numbers by the two methods used. Abbott and Farley ${ }^{6)}$ have suggested that base number of used oil by the acetic acid method sometimes gives

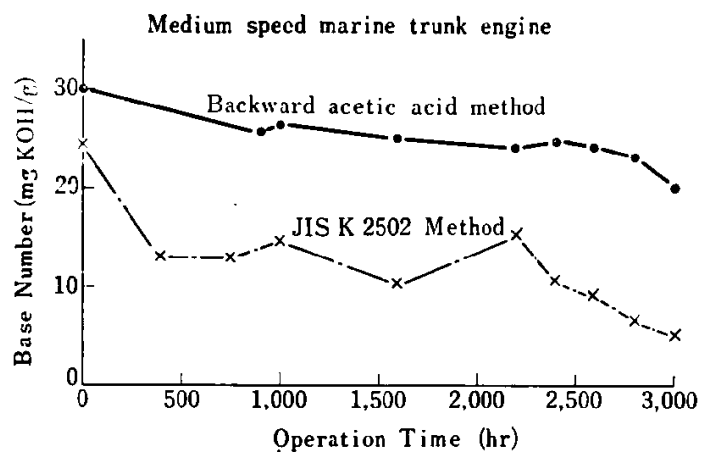

Fig. 6 Change in Base Numbers of Marine Lubricating Oil through Engine Operation high and erratic value, and that analyses of used oils by this method must be interpreted with caution until additional data are available. Thereafter further details have not been published.

The purpose of the following experiments is to clarify this point. Because the theoretical base number of used oil can not be obtained, another criterion must be considered. The chief function of basic additives in diesel engine lubricating oils is to neutralize the sulfuric acid generated during the engine operation by combustion of the sulfur compounds in the fuel. Therefore, it is considered appropriate to examine the capacity of used oils for neutralizing sulfuric acid.

\section{Neutralizing Capacity for Sulfuric Acid}

The JIS and the backward acetic acid methods were compared with the sulfuric acid back titration method, because the results obtained with sulfuric acid titrant might directly show the amount of base that would neutralize sulfuric acid. However, it should be noted that the sulfuric acid back titration method is not suitable as a routine test method, because it sometimes requires excessive

Table 6 Base Numbers of Engine Used Oils and Laboratory Oxidation Test Oils

\begin{tabular}{|c|c|c|c|c|}
\hline \multirow[b]{3}{*}{$\begin{array}{l}\text { Engine Used Oils } \\
\text { Marine Lubricating Oils } \\
\text { Used in Marine Trunk } \\
\text { Engine } \\
\text { (Ca-Sulfonate } \\
\text { Ca-Phenate }\end{array}$} & \multirow[b]{3}{*}{$\begin{array}{l}\text { Operation Period } \\
\qquad \begin{array}{r}220 \mathrm{hr} \\
600 \mathrm{hr} \\
1,200 \mathrm{hr}\end{array}\end{array}$} & \multirow{3}{*}{$\begin{array}{c}\text { Sulfuric Acid Back } \\
\text { Titration Method } \\
\text { (mg KOH/g) } \\
\\
\\
\\
30.0 \\
25.7 \\
27.3\end{array}$} & \multicolumn{2}{|c|}{$\begin{array}{l}\text { Percent of Sulfuric Acid } \\
\text { Back Titration Method }\end{array}$} \\
\hline & & & $\begin{array}{c}\text { JIS } \mathrm{K} 2502 \\
\text { Method }\end{array}$ & $\begin{array}{c}\text { Backward Acetic Acid } \\
\text { Method }\end{array}$ \\
\hline & & & $\begin{array}{l}76 \\
49 \\
60\end{array}$ & $\begin{array}{r}104 \\
99 \\
102\end{array}$ \\
\hline $\begin{array}{l}\text { DM Grade Diesel Oils Used } \\
\text { in Bus } \\
\left.\text { ( } \begin{array}{l}\text { Ba-Phosphonate } \\
\text { Ashless Detergent }\end{array}\right)\end{array}$ & $\begin{array}{l}1,880 \mathrm{~km} \\
4,750 \mathrm{~km} \\
7,180 \mathrm{~km}\end{array}$ & $\begin{array}{l}3.83 \\
3.50 \\
3.08\end{array}$ & $\begin{array}{l}44 \\
40 \\
39\end{array}$ & $\begin{array}{l}110 \\
116 \\
117\end{array}$ \\
\hline $\begin{array}{l}\text { DM Grade Diesel Oils Used } \\
\text { in Laboratory Engine Test } \\
\text { (Ba-Phosphonate } \\
\text { Ashless Detergent })\end{array}$ & $\begin{array}{l}4 \text { cycle } \\
12 \text { cycle } \\
16 \text { cycle }\end{array}$ & $\begin{array}{l}5.76 \\
5.34 \\
4.93\end{array}$ & $\begin{array}{l}76 \\
32 \\
32\end{array}$ & $\begin{array}{r}105 \\
99 \\
98\end{array}$ \\
\hline $\begin{array}{l}\text { Oxidation Test Oils* } \\
\text { DS Grade Diesel Oils } \\
\text { (Ca-Sulfonate) }\end{array}$ & $\begin{array}{c}\text { Oxidation Period } \\
\text { New Oil } \\
12 \mathrm{hr} \\
24 \mathrm{hr}\end{array}$ & $\begin{array}{l}15.2 \\
15.1 \\
15.1\end{array}$ & $\begin{array}{l}91 \\
57 \\
34\end{array}$ & $\begin{array}{l}99 \\
99 \\
99\end{array}$ \\
\hline $\begin{array}{l}\text { DM Grade Diesel Oils } \\
\left(\begin{array}{l}\text { Ba-Phosphonate } \\
\text { Ca Sulfonate } \\
\text { Ca-Phenate } \\
\text { Ashless Detergent }\end{array}\right)\end{array}$ & $\begin{array}{l}\text { New Oil } \\
12 \mathrm{hr} \\
24 \mathrm{hr}\end{array}$ & $\begin{array}{l}8.04 \\
6.42 \\
5.40\end{array}$ & $\begin{array}{l}78 \\
24 \\
15\end{array}$ & $\begin{array}{r}101 \\
100 \\
96\end{array}$ \\
\hline $\begin{array}{l}\text { MS Grade Motor Oils } \\
\text { (Ca-Sulfonate) }\end{array}$ & $\begin{array}{c}\text { New Oil } \\
12 \mathrm{hr} \\
24 \mathrm{hr}\end{array}$ & $\begin{array}{l}7.04 \\
6.61 \\
5.87\end{array}$ & $\begin{array}{l}91 \\
39 \\
20\end{array}$ & $\begin{array}{r}109 \\
97 \\
102\end{array}$ \\
\hline
\end{tabular}

* JIS K 2514 "Testing Method for Oxidation Stability for Internal-Combution Engine Lubricating Oils". 
titration time, and in some used oils inflection point is difficult to define.

Table 6 shows that the base numbers by the backward acetic acid method agree very well with the values obtained by the sulfuric acid back titration method for both used oils and laboratory oxidation test oils ${ }^{9}$, while the JIS method gives significantly lower values. Interestingly enough, though JIS base numbers of used oils show early depletion even in the case of oxidation test oils, it is not believable that the capacity for neutralizing sulfuric acid is depleted by oxidation. In fact, when an oxidized straight oil having the acid number of $5 \mathrm{mg} \mathrm{KOH} / \mathrm{g}$ was mixed with a high base number oil in equal ratio and stirred for 30 minutes at $90^{\circ} \mathrm{C}$, the base numbers by both the JIS and the backward acetic acid methods did not show any substantial decrease.

From these facts, it can be concluded that the base numbers by the JIS method do not indicate the true neutralizing capacity for sulfuric acid, but they show significantly lower values. To determine whether the basic substances in the oil react quantitatively with sulfuric acid or not, the base numbers were determined for oils treated with reagent grade sulfuric acid of $96 \%$ concentration for $4-8$ hours. The result using an oil containing calcium sulfonate is given in Fig. 7. It is clear that the decrease in base number by any method agrees well with the theoretical decrease. Similar results were obtained for both the oils containing calcium phenate and the oils containing calcium phenate and ashless detergent. Since the JIS method also gives the theoretical decrease, it can be considered that another factor other

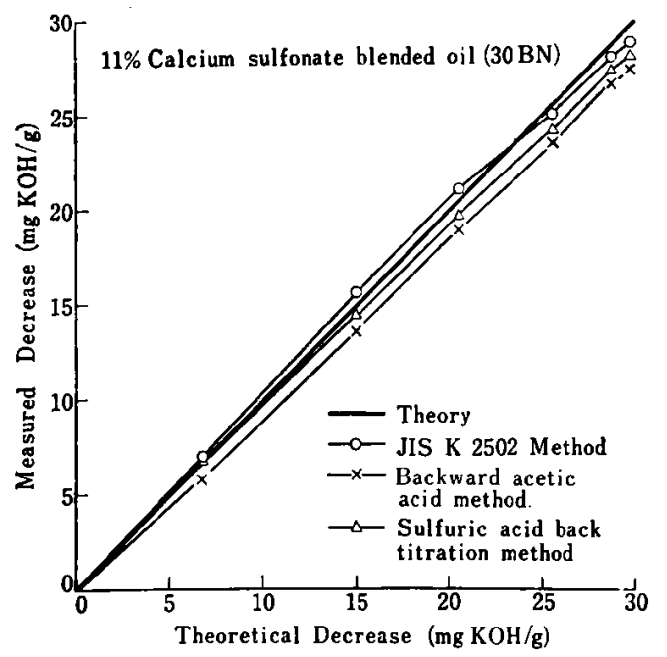

Fig. 7 Decrease in Base Numbers by Reaction with Concentrated Surfuric Acid than sulfuric acid neutralization largely contributes to the early depletion of the JIS base numbers in used oils. As seen in Fig. 7, the decrease in base number by both the backward acetic acid and the sulfuric acid back titration methods is somewhat smaller than the theoretical decrease; but the difference is practically negligible. To make sure that the neutralized product is not titrated by the backward acetic acid method, calcium sulfate $\left(\mathrm{CaSO}_{4} \cdot 2 \mathrm{H}_{2} \mathrm{O}\right)$ has been titrated by the three methods. The results show that the backward acetic acid and the sulfuric acid back titration methods titrate only $1-2$ percent of calcium sulfate. Since these are practically negligible values, it is not likely that these two methods give erratically high base numbers due to the already neutralized products being titrated.

\section{Correlation of Base Number of Used Oil with Engine Performance}

As described previously, laboratory analyses for used oils have indicated that the backward acetic acid method is the better determination method of neutralizing capacity for sulfuric acid than is the JIS method. For further comfirmation, some engine tests have been carried out.

Table 7 shows an engine test result for a marine engine used oil $\left(A_{1}\right)$ which shows a remarkable difference between the base numbers by the JIS and the backward acetic acid methods. For comparison, the results by the same engine test for three new oils $\left(A_{2}, B\right.$ and $G$ ) are also shown in Table 7. Where, $A_{2}$ is the new oil of the marine engine used oil $\left(A_{1}\right), B$ is a new oil having about the same JIS base number as that of $A_{1}$, and $C$ is another new oil having about the same backward acetic acid base number as that of $A_{1}$. Engine rating and wear results for $A_{1}$ are far better than those for $B$, and about the same as those for $C$. It is very clear that the correct base number of the marine engine used oil $\left(A_{1}\right)$ should be almost the same as its backward acetic acid base number.

Fig. 8 shows the change of base numbers of DS grade diesel oil during engine test, the conditions of which are shown in Table 8 . JIS base numbers are also repidly depleted in the early periods in this case. Considering that sulfuric acid is generated under the constant fuel supply rate, the base numbers should constantly and gradually decrease as in the case of backward acetic acid base numbers. Abbott and Farley ${ }^{6}$ have suggested that high values by the acetic 
Table 7 Laboratory Engine Test Results of Marine Trunk Engine Used Oil and Other Reference Oils

\begin{tabular}{|c|c|c|c|c|}
\hline & \multirow{2}{*}{$\begin{array}{c}4,500 \mathrm{hr} \text { Used Oil } \\
\text { in Marine Trunk } \\
\text { Engine } A_{1}\end{array}$} & \multirow{2}{*}{$\begin{array}{l}\text { New Oil in Marine } \\
\text { Trunk Engine } A_{2}\end{array}$} & \multicolumn{2}{|c|}{ Other New Oils } \\
\hline & & & B & G \\
\hline $\begin{array}{l}\text { Characteristics of Test Oils } \\
\text { Base Number (mg KOH/g) } \\
\text { JIS K 2502 Method } \\
\text { Backward Acetic Acid Method } \\
\text { Acid Number (mg KOH/g) } \\
\text { Viscosity (cSt)@ } 37.78^{\circ} \mathrm{C} \\
\text { @ } 98.89^{\circ} \mathrm{C}\end{array}$ & $\begin{array}{c}4.90 \\
15.5 \\
2.67 \\
114.9 \\
11.34\end{array}$ & $\begin{array}{c}24.3 \\
31.3 \\
1.49 \\
119.8 \\
11.53\end{array}$ & $\begin{array}{r}4.33 \\
5.40 \\
0.68 \\
119.1 \\
11.42\end{array}$ & $\begin{array}{c}9.75 \\
12.5 \\
0.87 \\
126.4 \\
12.00\end{array}$ \\
\hline $\begin{array}{l}\text { Engine Rating } \\
\text { Cleanliness (100=clean) } \\
\text { Top Ring Wear (mg) }\end{array}$ & $\begin{array}{r}81 \\
107\end{array}$ & $\begin{array}{l}98 \\
41\end{array}$ & $\begin{array}{r}71 \\
261\end{array}$ & $\begin{array}{r}75 \\
181\end{array}$ \\
\hline
\end{tabular}

Test conditions : Fuel $\cdots$ fuel oil A (viscosity @ $50 \mathrm{C} 2.76 \mathrm{cSt}$, carbon residue $0.51 \%$, sulfur is adjusted to $3.0 \%$ ). Engine...YAMMER F-4 diesel engine (single cyl., $4.5 \mathrm{HP}(0,2,000 \mathrm{rpm}$ ).

Operating conditions $\cdots$ speed $2,000 \mathrm{rpm}$, oil temp. $78^{\circ} \mathrm{C}$, load $3.0 \mathrm{ps}$, cooling jacket temp. $90^{\circ} \mathrm{C}$, time $120 \mathrm{hr}$.

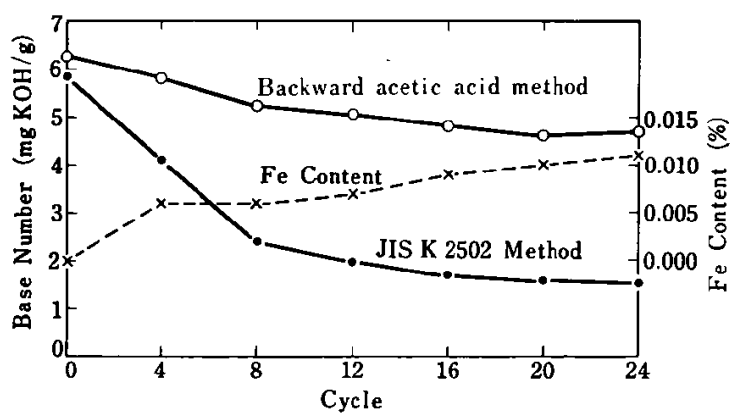

Fig. 8 Change in Base Numbers of DS Grade Diesel Oil through Laboratory Engine Test Shown in Table 8

Table 8 Laboratory Engine Test Results of DS Grade Diesel Oil

\begin{tabular}{lr|ll}
\hline \multicolumn{1}{c|}{ Cleanliness (10=clean) } & \multicolumn{2}{|c}{$\begin{array}{c}\text { Were (Average, Weight } \\
\text { Loss \%) }\end{array}$} \\
\hline Ring Sticking & 9.9 & Connecting Rod & 0.010 \\
Piston Skirt Deposits & 7.4 & Bearing & 0.019 \\
Ring Land Deposits & 0.6 & Main Bearing & 0.68 \\
Ring Groove Carbon & 7.8 & Compression Ring & 0.68 \\
Ring Groove Deposits & 1.5 & & \\
Oil Ring Deposits & 10.0 & & \\
\hline
\end{tabular}

Test conditions : Fuel $\cdots$ diesel gas oil (sulfur $0.98 \%$ ).

Engine...NISSAN UD 33 (3 cyl., 110 HP @ $2,000 \mathrm{rpm}$ ).

Operating conditions $\cdots A$ cycle consisting three stages.

$\begin{array}{lccc} & \text { Stage I } & \text { Stage II } & \text { Stage III } \\ \text { Speed (rpm) } & 600 & 2,200 & 1,500 \\ \text { Load (ps) } & 0 & 110 & 70 \\ \text { Oil temp. ( C) } & 50 & 120 & 100 \\ \text { Time (min) } & 30 & 60 & 150 \\ \text { Number of cycles : } 24 & & \end{array}$

acid method for used oils may be caused by metallic particles, produced from engine wear. However, as shown in Fig. 8, iron content is very small, and even if all of it is assumed to be $\mathrm{Fe}^{+++}$, $0.015 \%$ iron would correspond to only 0.45 $\mathrm{mgKOH} / \mathrm{g}$, and this could not be the cause for the high values. Though JIS base numbers for this test are sharply depleted, engine rating and wear are fairly good as shown in Table 8.

Fig. 9 shows the change in base numbers of MM grade motor oil during GRC L-38 engine test using iso-octane as the fuel free from sulfur. The same phenomenon as shown in Fig. 8 is also observed in this case. Channam and Potter ${ }^{10}$ ) have postulated that rapid and early base number depletion is caused by additives plating out on the metal surface. However, considering the fact that backward acetic acid base numbers do not significantly decrease, it is likely that the rapid and early depletion of JIS base numbers is caused,

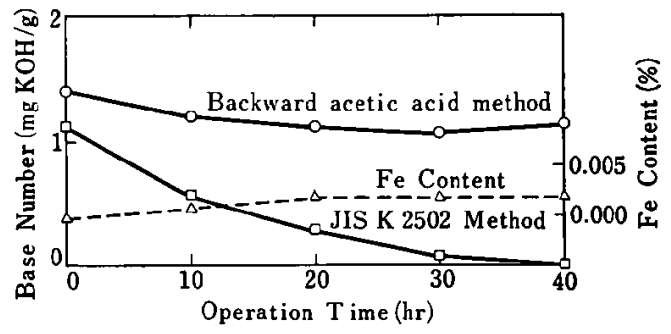

Fig. 9 Change in Base Numbers of MM Grade Motor Oil through Laboratory Engine Test Shown in Table 9

Table 9 Laboratory Engine Test Results of MM Grade Motor Oil

\begin{tabular}{ll|lc}
\hline \multicolumn{1}{c|}{ Varnish (10=clean) } & \multicolumn{2}{|c}{ Sludge (10=clean) } \\
\hline Piston Skirt & 10 & Locker & 10 \\
Locker Cover & 10 & Locker Cover & 10 \\
Push Rod Cover & 10 & Push Rod Cover & 10 \\
Cylinder Wall (Below & & Oil Screen & 10 \\
Cylinder Travell) & 10 & Oil Pan & 9.5 \\
Oil Pan & 10 & Crankcase Cover Plate & 10 \\
Crankcase Cover Plate & 10 & & \\
\hline
\end{tabular}

Connecting Rod Bearing Wear $55.0 \mathrm{mg}$

Fuel $\cdots \cdots$ iso-octane (TEL $3.0 \mathrm{ml} / \mathrm{gal}$ ).

Engine...CLR engine.

Operating condition...CRC L-38. 
at least, in this case by another reason. Though JIS base number has decreased almost to nil toward the end of this test, engine rating and wear are fairly good as shown in Table 9.

From the results of the above three engine tests, it is concluded that the backward acetic acid method gives reasonable base numbers for evaluating engine performance, whereas the JIS method gives unreasonably low base numbers.

\section{Reason for the JIS Method Giving Lower Base Number}

One of the defects of the JIS method is the slowness of reaction of the base components in the oil with hydrochloric acid titrant. So the ordinary speed titration (ordinary method) and the extremely slow speed titration (prolonged method) were compared for a new and used oils, respectively. The ordinary method was made in such a manner that the cell potential after each addition of titrant into the system was considered constant when it changed less than $0.1 \mathrm{pH}$ reading per minute and then the next titrant was to be added. The prolonged method was made in such a manner that each addition of titrant was limited to $0.1 \mathrm{~m} l$ and the interval of $20 \sim 40$ minutes was kept before each addition.

The titration curves are shown in Fig. 10 (for new oil) and Fig. 11 (for used oil). In the prolonged method, it can be concluded that the width between both curves just after $0.1 \mathrm{~m} l$ titration and after waiting for $20 \sim 40$ minutes means that base components in the sample are reacting very slowly with hydrochloric acid titrant. The JIS

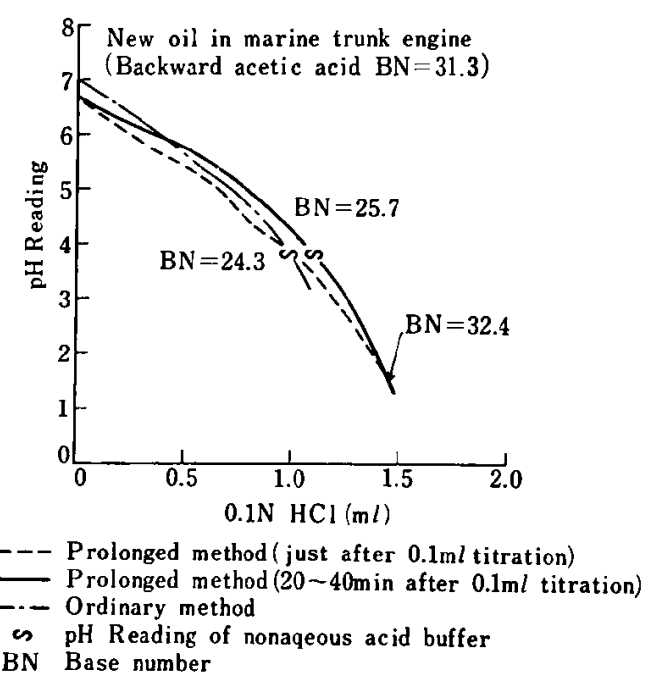

Fig. 10 Titration Curves by Ordinary and Prolonged JIS K 2502 Methods

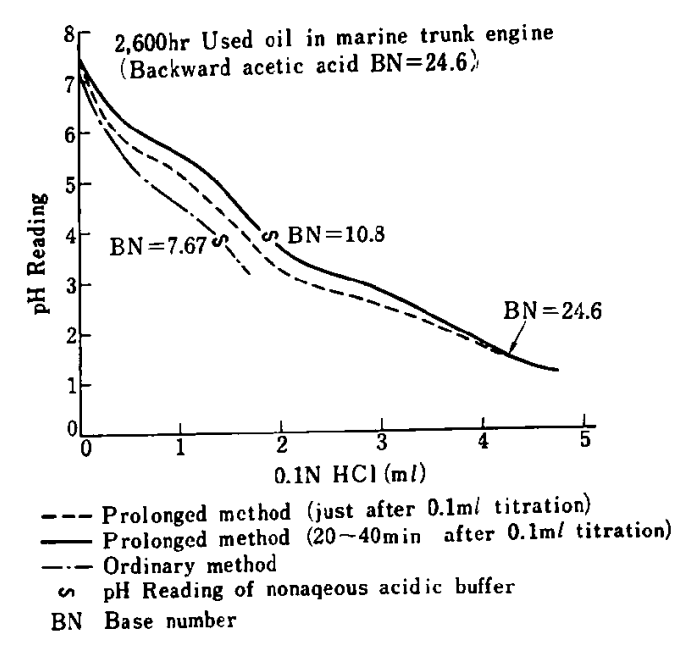

Fig. 11 Titration Curves by Ordinary and Prolonged JIS K 2502 Methods

method specifies that if no clear inflection appears, one should mark the end point at the meter reading corresponding to the nonaqueous acid buffer $(3.80 \mathrm{pH}$ reading in this experiment), but in this case, such a method will stop the titration at the point still showing the meter reading reversion, that is, at the point of another base component remaining to be titrated. The amount of titrant for used oil from the $\mathrm{pH}$ reading 3.80 to no meter reading reversion point is far larger than that for new oil. This is considered to be due to the components, which may be difficult to titrate accurately by the JIS method, contained more in the used oil than in the new oil. The prolonged base numbers corresponding to the no meter reading reversion points are similar to the backward acetic acid base numbers.

\section{Conclusion}

(1) The acetic acid method is most satisfactory with regard to accuracy, precision and rapidness

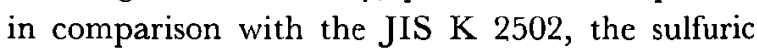
acid back titration and the methyl isobutyl ketone methods. However, this method can not be generally applied to used oils, because a sharp inflection sometimes fails to appear in the titration curve.

The backward acetic acid method has been developed to eliminate this defect. This backward method yields the base numbers essentially identical with those by the forward method for additives and new oils. In order to obtain precise results, the sample size should be so chosen that the back titration is from 30 to 70 percent of the blank.

(2) Since a remarkable difference between 
the base numbers of used engine oils by the JIS and the backward acetic acid methods has been observed, laboratory analyses and engine tests have been made to determine which method gives the valid base numbers. The results have shows that the backward acetic acid method gives the valid values as the measure of neutralizing capacity for sulfuric acid and as the function of engine performance, while the JIS method gives significantly lower values.

In addition, from the comparison of ordinary and prolonged JIS methods, it has been found that the reason for the JIS method giving lower values, especially for used oils, is due to the components contained more in the used oil than in the new oil, which may be difficult to titrate accurately by the JIS method.

\section{References}

1) Stewart, W. T., Stuart, F. A., "Advances in Petro- leum Chemistry and Refining", Vol. 7, Chapter 1 (1963).

2) Dyson, A. et al., Proc. Inst. Mech. Engrs., 171, 717 (1957).

3) Tyulyaev, V. N. et al., Chem. and Tech. of Fuels and Oils (Translated from Russian), No. 4, 275 (1967).

4) Glaser, W., die Technischen Arbeitstagung des Verband Süddeutshe Mineralölwritschaft, März 31, 1965.

5) Japanese Industrial Standards, JIS K 2502-1969 "Testing Method for Neutralization Number of Petroleum Products by Potentiometric Titration".

6) Abbott, A. D., Farley, L. L., Lubrication Eng., 24, (9), 422 (1968)

7) Oronite Chemical Co., "Procedure for the Determination of the Alkalinity Value of Additives and Blended Lubricating Oils".

8) 1966 Book of ASTM Standards, Part 18; "Proposed Recommended Practices for Applying Precision Data Given in ASTM Method of Test for Petroleum Products and Lubricants".

9) Japanese Industrial Standards, JIS K 2514-1959 "Testing Method for Oxidation Stability for InternalCombustion Engine Oils".

10) Channam, F. E., Potter, R. I., SAE Paper 670498, $S A E J ., 76,(5), 56$ (1968). 